\title{
Perbedaan Higher Order Thinking Skills pada Model Problem Based Learning dan Model Konvensional
}

\author{
Rizky Tyas Aria Kurniasari ${ }^{1}$, Supriyono Koeshandayanto ${ }^{2}$, Sa'dun Akbar $^{3}$ \\ ${ }^{1}$ Pendidikan Dasar-Universitas Negeri Malang \\ ${ }^{2}$ Pendidikan Fisika-Universitas Negeri Malang \\ ${ }^{3}$ Keguruan Sekolah Dasar dan Prasekolah-Universitas Negeri Malang
}

\section{INFO ARTIKEL}

\section{Riwayat Artikel:}

Diterima: 28-06-2019

Disetujui: 12-02-2020

Kata kunci:
problem based learning;
higher order thinking skills;
conventional model;
problem based learning;
higher order thinking skills;
model konvensional

\section{Alamat Korespondensi:}

Rizky Tyas Aria Kurniasari

Pendidikan Dasar

Universitas Negeri Malang

Jalan Semarang 5 Malang

E-mail: rizky.tias@um.ac.id

\section{ABSTRAK}

Abstract: Thematic learning carried out in elementary schools has not trained students high-level thinking skills as a whole due to the use of learning models that tend to be monotonous and make students bored. This study aims to determine the effect of the Problem Based Learning (PBL) model on HOTS (Higher Order Thinking Skillls). The research method used is quantitative experiments with the design of nonequivalent group design. The results showed that the teacher's implementation was sufficient in accordance with the syntax of the PBL learning model so that it could influence HOTS students. The difference in HOTS scores between the two classes is indicated by the average post-test scores. The use of PBL models should be implemented for students to be able to train HOTS students.

\begin{abstract}
Abstrak: Pembelajaran tematik yang dilaksanakan di SD belum melatihkan kemampuan berpikir tingkat tinggi siswa secara keseluruhan dikarenakan penggunaan model pembelajaran yang cenderung monoton dan membuat siswa jenuh. Penelitian ini bertujuan untuk mengetahui pengaruh model Problem Based Learning terhadap Higher Order Thinking Skillls. Metode penelitian yang digunakan yaitu kuantitatif eksperimen dengan desain nonequivalent group design. Hasil penelitian menunjukan bahwa keterlaksanaan guru sudah cukup sesuai dengan sintaks model pembelajaran $P B L$ sehingga dapat berpengaruh terhadap HOTS siswa. Perbedaan skor HOTS antara dua kelas ditunjukkan oleh rata-rata nilai post-test. Penggunaan model PBL hendaknya dapat diimplementasikan kepada siswa agar dapat melatih HOTS siswa.
\end{abstract}

Berdasarkan tantangan pendidikan di abad ke-21 bahwa pendidikan harus mampu membentuk lingkungan belajar dengan menggunakan proses cara berpikir dan mencari pengetahuan bagi siswa sehingga dapat memunculkan pribadi yang aktif, kolaboratif, dan mandiri. Peran pendidik untuk memungkinkan siswa dapat mengenali berbagai perspektif berpikir sehingga mampu mengaktualisasikan diri untuk menghadapi masalah dunia nyata. Hal ini dapat dilakukan dengan membelajarkan siswa menggunakan model pembelajaran yang diimplementasikan oleh guru. Model Problem Based Learning dapat melatihkan siswa agar dapat menghadapi, mengatasi, dan menyelesaikan masalah dalam kehidupan nyata. Dengan Problem Based Learning, siswa ditberikan peluang agar dapat menjelajah berbagai informasi agar dapat menghubungkan pembelajaran dengan kebutuhan mereka sendiri sebagai siswa dan mampu mengembangkan kemandirian dalam penyelidikan masalah (Rahman, 2016). Pembelajaran Problem Based Learning $(P B L)$ merupakan model pembelajaran inovatif yang dapat mengkondidikan siswa agar dapat belajar secara aktif. Pernyataan tersebut dapat didukung oleh pernyataan dari Suprihatiningrum (2017) bahwa model pembelajaran berbasis masalah merupakan suatu model pembelajaran yang menempatkan siswa sejak awal dihadapkan masalah, kemudian diikuti oleh proses pencarian informasi. Dengan demikian, penggunaan model Problem Based Learning dapat membuat siswa lebih aktif dan dapat memacu siswa dalam menggunakan kemampuan berpikir lebih tinggi karena siswa dapat mengasosiasikan suatu masalah yang kemudian dengan melalui pemecahan masalah, melalui pemecahan masalah tersebut siswa belajar keterampilan-keterampilan yang lebih mendasar (Sumantri, 2015).

Selain model pembelajaran, siswa membutuhkan keterampilan yang harus dilatihkan agar lebih terampil dalam berpikir terutama kemampuan berpikir tingkat tinggi atau yang sering dikenal dengan Higher Order Thinking Skills (HOTS). Melatihkan HOTS sangat penting untuk dilatihkan kepada siswa dikarenakan guna mendukung tantangan pendidikan abad 21 agar siswa dapat berpartisiapasi dengan baik dalam kegiatan belajar di sekolah. Keterampilan HOTS ini sangat penting untuk dilatihkan kepada siswa karena dalam proses belajar mengajar pengembangan HOTS sangat dibutuhkan untuk memecahkan masalah 
dalam proses belajar. $P B L$ merupakan salah satu model pembelajaran yang dirancang dengan bertujuan untuk meningkatkan Higher Order Thingking Skills (HOTS). Pernyataan tersebut sesuai dengan pernyataan Suprihatiningrum (2017) menyatakan bahwa pembelajaran berdasarkan masalah merupakan pendekatan efektif untuk pembelajaran proses HOTS. Model ini berdasarkan paradigma konstruvistik dengan strategi student centered yang dapat membantu dan membentuk siswa agar dapat menentukan dan menemukan masalah serta pemecahannya. Dengan demikian siswa difasilitasi dan diarahkan untuk dapat mengkonstruksi pengetahuannya sendiri baik secara individu maupun kelompok dalam tim atau kelompok. Hal ini tentu dapat memberikan kesempatan besar bagi siswa untuk dapat meningkatkan Higher Order Thingking Skills (HOTS).

HOTS dilatihkan kepada siswa sesuai dengan tingkatan kognitif yang sesuai dengan Taksonomi Bloom. Tingkatan kognitif ini terdiri dari keterampilan menganalisis, mengevaluasi, dan mencipta. Ketiga tingkatan kognitif perlu untuk dilatihkan kepada siswa agar siswa secara aktif dan mandiri dapat menggunakan kemampuan berpikirnya untuk menalar sesuatu yang dia hadapi. Siswa melakukan aktivitas evaluasi agar siswa mampu menilai kembali pemahaman yang sudah digunakan setelah melakukan kegiatan menganalisis. Mencipta merupakan tingkatan kognitif tertinggi dalam Taksonomi Bloom. Kemampuan mencipta tidak mudah untuk dilakukan karena sangat membutuhkan kreativitas yang tinggi dalam menciptakan sesuatu. Ketiga tingkatan tersebut perlu dilatihkan kepada siswa agar siswa dapat bersaing di era global.

Secara umum, pembelajaran tematik yang dilaksanakan di SD belum banyak menggunakan model pembelajaran dan melatihkan Higher Order Thinking Skills (HOTS) kepada siswa secara keseluruhan. Hal ini sesuai dengan observasi awal yang dilakukan oleh peneliti, guru di sekolah masih belum membelajarkan siswa dengan menggunakan model yang sesuai dengan kondisi dan tuntutan belajar siswa. Guru menggunakan salah satu model pembelajaran, namun belum paham tata cara pelaksanaannya sehingga belum mampu mengondisikan siswa dalam kegiatan belajar di dalam kelas. Guru mengharapkan siswa dapat memecahkan suatu masalah yang telah disajikan, namun dalam pelaksanaannya siswa masih belum mampu. Hal ini dikarenakan guru masih kebingungan dan tidak memancing siswa untuk lebih aktif menggunakan keterampilan berpikir siswa. Tentu saja hal ini belum dapat melatihkan siswa untuk dapat mengolah dan mengembangkan keterampilan berpikir mereka ke level yang lebih tinggi.

Dari hasil penelitian terdahulu yang dilakukan oleh Fatchyah (2016), penggunaan model Problem Based Learning dilakukan untuk melatihkan HOTS melalui ekperimen. Namun, yang berebeda dari penelitian sebelumnya adalah penggunaan soal pre-test dan post-test untuk mengukur HOTS siswa. Pada penelitian Fatchiyah soal tes yang diberikan kepada siswa masih bercampur dengan soal berbasis $\mathrm{C} 1-\mathrm{C} 3$ atau yang sering dikenal dengan istilah Lower Order Thinking Skills, sedangkan pada penelitian ini siswa yang diteskan diberikan soal tes yang mencakup HOTS secara keseluruhan dan terdiri dari soal pilihan ganda dan uraian. Penerapan soal-soal tersebut dimaksudkan agar dapat mengatahui sejauh mana siswa dapat menyusun ide atau gagasan siswa dalam berupa kalimat tidak hanya menjawab secara obyektif saja. Tugas setiap pertemuan pembelajaran dirancang menggunakan keterampilan C4-C6 dalam bentuk lembar diskusi maupun individu. Hal ini dimaksudkan agar siswa terlatih dan terbiasa menggunakan HOTS.

Dari hasil wawancara juga diperoleh informasi bahwa guru sebenarnya sudah mengenal Problem Based Learning, namun belum menerapkan dengan baik dan ditemukan pula terdapat guru yang sudah menerapkan tapi tidak sesuai dengan sintaks Problem Based Learning. Kesenjangan tersebut mengakibatkan penerapan Problem Based Learning di sekolah masih belum maksimal. Melalui Problem Based Learning peserta didik diharapkan bisa menemukan konsep dari materi yang dipelajari secara mandiri. Siswa belum terlibat penuh dalam proses pemecahan masalah. Pemberian masalah dan pemecahan masalah masih sering dilakukan sendiri oleh guru sehingga siswa hanya menerima dan menanggapim, namun tidak dilatih untuk mencari pemecahan masalah. Berdasarkan latar belakang di atas, maka rumusan masalah dalam penelitian ini adalah adakah pengaruh model Problem Based Learning (PBL) terhadap HOTS (Higher Order Thinking Skillls) pada siswa kelas V SDN Blimbing 1 Kota Malang.

\section{METODE}

Rancangan penelitian yang digunakan yaitu eksperimental semu (quasi experiment) dengan menggunakan desain penelitian nonequivalent group design. Ada dua kelompok berbeda yang digunakan dalam penelitian ini. Kedua kelompok yang berbeda tersebut diberikan pre-test dan post-test. Pada kelas eksperimen diberikan perlakuan dengan menggunakan model Problem Based Learning, sedangkan kelas kontrol menggunakan model konvensional yang dilakukan dengan ceramah dan diskusi.

Subjek dalam penelitian ini menggunakan siswa kelas V semester I di SDN Blimbing 1 tahun pelajaran 2018 -2019. Terdapat dua kelas pada kelas V yaitu VA sebanyak 40 siswa sebagai kelas kontrol dan VB sebanyak 42 siswa sebagai kelas eksperiman. Kelas kontrol dan eksperimen dipilih berdasarkan hasil dari nilai pre-test yang memiliki nilai rata-rata berbeda. Instrumen pada penelitian ini meliputi instrument perlakuan dan instrument pengukuran. Instrumen perlakuan dalam penelitian ini berupa perangkat pembelajaran yang digunakan diantaranya meliputi silabus pembelajaran untuk subtema "Perpindahan Kalor di Sekitar Kita", rencana pelaksanaan pembelajaran yang disusun berdasarkan kurikulum 2013 dan skenario belajar siswa dengan model Problem Based Learning dan konvensional. Instrumen pengukuran berupa alat yang digunakan untuk mengukur hasil perlakuan terhadap Higher Order Thinking Skills dalam bentuk tes (soal) dan lembar observasi. Penelitian ini menggunakan teknik analisis kovarian (ANCOVA). Uji ANCOVA bertujuan untuk mengetahui perbedaan Higher Order Thinking Skills antara kelas eksperimen yang diberikan perlakuan dan kelas kontrol yang tidak diberikan perlakuan. 


\section{HASIL}

Proses pembelajaran yang dilakukan oleh dua kelas pada penelitian ini yaitu pembelajaran menggunakan model Problem Based Learning dan model konvensional. Materi yang dibelajatkan pada penelitian ini yaitu tema "Perpindahan Kalor" dengan subtema "Perpindahan Kalor di Sekitar Kita" yang dilakukan sebanyak enam kali pertemuan dengan alokasi waktu 6 x 35 menit. Pertemuan pertama membahas tentang perpindahan konduksi, pertemuan kedua membahas tentang perpindahan konveksi, pertemuan ketiga membahas tentang kehidupan nelayan pemburu paus, pertemuan keempat membahas tentang kegiatan pelelangan nelayan, pertemuan kelima membahas tentang perpindahan kalor secara radiasi, dan pertemuan keenam membahas tentang warga negara terhadap hak dan kewajibannya. Kegiatan pertama yang dilakukan yaitu dengan pemberian pre-test. Hasil yang diperoleh dari pre-test akan ditentukan adanya kesamaan atau tidak. Data pengetahuan awal siswa dari kedua kelas tersebut dapat dilihat pada tabel 1 .

Tabel 1. Nilai Pengetahuan Awal Siswa

\begin{tabular}{lll}
\hline \multirow{2}{*}{ Hasil } & \multicolumn{2}{c}{ Nilai Pengetahuan Awal } \\
\cline { 2 - 3 } & Kelas Eksperimen & Kelas Kontrol \\
\hline Jumlah siswa & 41 & 40 \\
Nilai Maksimum & 67 & 67 \\
Nilai minimum & 40 & 40 \\
Rata-rata & 55,15 & 57,40 \\
Standar Deviasi & 6,81 & 8,14 \\
\hline
\end{tabular}

Setelah dilakukan pemberian pre-test, siswa yang berasal dari dua kelompok diberikan perlakuan yang berbeda namun tidak pada materi. Perlakuan yang diberikan pada kelas eksperimen yaitu dengan menggunakan model Problem Based Learning dan kelas kontrol menggunakan model konvensional dalam proses belajarnya. Setelah diberikan perlakuan yang berbeda terhadap dua kelompok tersebut selama enam kali pertemuan, kemudian diberikan post-test yang digunakan untuk mengetahui hasil dari perlakuan yang diberikan oleh guru. Pemberian pre-test bertujuan untuk mengetahui ada atau tidaknya perbedaan HOTS dari kelas yang diberikan perlakuan. Data HOTS dari kedua kelas dan kelompok yang berbeda disajikan pada tabel 2.

Tabel 2. Data Nilai Posttest HOTS

\begin{tabular}{lcc}
\hline \multirow{2}{*}{ Hasil } & \multicolumn{2}{c}{ Nilai Post-test } \\
\cline { 2 - 3 } & Kelas Eksperimen & Kelas Kontrol \\
\hline Jumlah siswa & 41 & 40 \\
Nilai Maksimum & 100 & 93 \\
Nilai minimum & 63 & 37 \\
Rata-rata & 80,12 & 60,63 \\
Standar Defiasi & 10,13 & 13,15 \\
\hline
\end{tabular}

Berdasarkan tabel diatas menunjukkan adanya perbandingan skor penilaian post-test Higher Order Thinking Skills pada kelas eksperimen dankelas kontrol. Rata-rata skor post-test pada kelas eksperimen $(\bar{x}=80,12)$ lebih tinggi daripada siswa yang dibelajarkan dengan model konvensional $(\bar{x}=60,63)$. Setelah dilakukan pemberian post-test, langkah selanjtunya dilakukan uji hipotesis untuk mengetahui ada tidaknya pengaruh dari dua kelompok yang berbeda dengan diberikan perlakuan terhadap HOTS. Uji hipotesis pada penelitian ini dilakukan dengan bantuan program SPSS 22.0 for windows menggunakan uji ANACOVA. Hasil uji hipotesis dapat dituliskan pada tabel 3.

Tabel 3. Hasil Uji Hipotesis

\begin{tabular}{lllllll}
\hline Source & Type III Sum of Squares & df & Mean Square & F & Sig. & Partial Eta Squared \\
\hline Corrected Model & $7697.061^{\mathrm{a}}$ & 2 & 3848.531 & 27.669 & .000 & .415 \\
Intercept & 6952.034 & 1 & 6952.034 & 49.982 & .000 & .391 \\
Pretest & .580 & 1 & .580 & .004 & .949 & .000 \\
Grup_Kelas & 7502.435 & 1 & 7502.435 & 53.939 & .000 & .409 \\
Error & 10849.186 & 78 & 139.092 & & & \\
Total & 421066.000 & 81 & & & & \\
Corrected Total & 18546.247 & 80 & & & & \\
\hline
\end{tabular}

Berdasarkan tabel diatas diperoleh informasi dari hasil penghitungan data didapatkan nilai signifikansi pada grup kelas yaitu 0,000 pada taraf signifikansi $\alpha=5 \%$. Hal ini berarti nilai signifikansi $(0,000)<0,05$. Jika nilai signifikansi berada di bawah 0,05 maka $\mathrm{H}_{0}$ ditolak. Dengan demikian, dapat disimpulkan bahwa secara simultan ada grup kelas antara grup eksperimen dan kontrol berpengaruh terhadap nilai yang diperoleh siswa. 


\section{PEMBAHASAN}

Data hasil penelitian yang telah dipaparkan di atas menunjukkan bahwa ada pengaruh signifikan dalam penggunaan model Problem Based Learning terhadap HOTS siswa. Pernyataan tersebut sesuai dengan pernyataan Royantoro (2018) bahwa model pembelajaran Problem Based Learning berpengaruh terhadap HOTS peserta didik. Berdasarkan hasil uji N-gain, terlihat perbedaan HOTS pada kelas eksperimen 0,62 sedangkan kelas kontrol 0,43. Hasil uji hipotesis post-test menunjukkan bahwa nilai sig. (2-tailed) adalah 0,000, dimana nilai signifikan lebih kecil dari nilai $\alpha=0,05$. Karena nilai sig $(2$-tailed) $<0,05$, maka Ho ditolak atau dapat disimpulkan bahwa terdapat pengaruh yang signifikan HOTS peserta didik yang diajar menggunakan model PBL dengan yang diajar menggunakan model konvensional.

HOTS adalah salah satu keterampilan berpikir yang sangat penting untuk dilatihkan kepada siswa. Melatih siswa dalam menggunakan HOTS bertujuan agar siswa mampu menghadapi berbagai tantangan yang ada. HOTS pada ranah kognitif tidak hanya sekedar mengingat dan memahami, namun menganalisis, mengevaluasi, dan mencipta. Selain itu, siswa dengan HOTS yang tinggi cenderung lebih berhasil dalam pembelajaran dibandingkan dengan peserta didik dengan kemampaun HOTS yang rendah (Tanujaya, Mumu, \& Margono, 2017). HOTS siswa pada masing-masing tingkatan kognitif dapat dilihat dengan melakukan analisis terhadap hasil belajar kognitif peserta didik. Tingkatan kognitif peserta didik terdiri dari tingkatan menganalisis, mengevaluasi, dan mencipta.

Pembelajaran menggunakan Problem Based Learning dapat melatih HOTS siswa, namun harus dilakukan secara berulang-ulang. Dalam penelitian ini, selama dilakukan pembelajaran dalam enam kali pertemuan dapat meningkatkan HOTS siswa terutama dalam menganalisis masalah, mengumpulkan data dan memecahkan masalah. Hal ini sesuai dengan pendapat Sumarmi (2012) bahwa penggunaan model Problem Based Learning dalam kegiatan pembelajaran dapat mengembangkan keterampilan berpikir siswa sehingga tidak hanya mencari sumber-sumber pengetahuan ketika pengetahuan bertambah namun juga adanya proses berpikir untuk mendapatkan pengetahuan baru merupakan yang terdiri dari mengumpulkan informasi/data, mambaca data, dan lain-lain yang penerapannya dilakukan melalui latihan dan pembiasaan.

Data HOTS siswa yang belajar menggunakan model Problem Based Learning dengan siswa yang belajar menggunakan model konvensional, diperoleh nilai rata-rata untuk kelas eksperimen yang dibelajarkan menggunakan model Problem Based Learning sebesar $(\bar{x}=80,12)$ dan kelas kontrol yang dibelajarkan menggunakan model konvensional sebesar $(\bar{x}=60,67)$. Jadi, dapat disimplkan bahwa nilai HOTS siswa yang belajar menggunakan model Problem Based Learning lebih unggul daripada siswa yang belajar menggunakan model konvensional. Pada hasil uji analisis ANCOVA diperoleh nilai signifikansi $(0,000)<(0,05)$ sehingga $\mathrm{H}_{\mathrm{o}}$ ditolak dan $\mathrm{H}_{1}$ diterima. Hal ini dapat dikatakan bahwa terdapat perbedaan yang signifikan antara Higher Order Thinking Skills (HOTS) siswa yang dibelajarkan menggunakan model Problem Based Learning dan siswa yang dibelajarkan menggunakan model konvensional.

Perbedaan yang terlihat pada HOTS siswa pada kelas kontrol dan kelas eksperimen merupakan buah dari penerapan $P B L$ dan model konvensional. Pada kelas eksperimen dibelajarkan dengan menggunakan model Problem Based Learning yang mendukung untuk dilatihkan kepada siswa agar dapat menggunakan kemampuan berpikir tingkat tinggi. Model Problem Based Learning memiliki karakteristik yaitu pembelajaran dimulai oleh adanya masalah. Masalah yang dimunculkan dapat berasal dari siswa atau guru, kemudian siswa memperdalam pengetahuannya tentang hal-hal yang telah diketahui oleh siswa untuk kemudian dicari solusi. Siswa juga dapat memilih masalah yang dianggap menarik untuk dicari solusinya sehingga siswa terdorong berperan aktif dalam proses belajar. Weissinger dalam Azmi (2016) juga menyatakan bahwa model Problem Based Learning memicu siswa agar lebih aktif dalam menghadapi masalah yang dimulai dari memahami, mengidentifikasi, dan menghubungkan dengan pengetahuan lain, dan menentukan pemecahan masalah dengan dilakukan berkolaborasi dengan membentuk kelompok-kelompok.

Siswa yang selama ini dibelajarkan menggunakan model pembelajaran konvensional memang sering merasa jenuh belajar seperti yang disampaikan (Ramawati, Maryani, Mulyana, 2016). Akhirnya berubah menjadi teratur belajarnya karena mereka fokus pada masalah dan motivasinya meningkat. Hal ini merupakan proses berpikir yang dilatih pada sintaks kedua Problem Based Learning. Siswa melakukan penyelidikan secara berkelompok menjadi tuntutan pada sintaks ketiga. Dalam penyelidikan siswa berlatih berpikir secara ilmiah sesuai prosedur penyelidikan. Hal ini menimbulkan kemampuan peserta didik menjadi lebih baik dalam menganalisis suatu permasalahan.

\section{SIMPULAN}

Berdasarkan hasil penelitian dan pembahasan dapat disimpulkan bahwa penelitian eksperimen yang telah dilakukan di SDN Blimbing 1 kota Malang yaitu keterlaksanaan guru dalam menerapkan model Problem Based Learning sudah cukup sesuai dengan sintaks model pembelajaran Problem Based Learning. Hasil penelitian juga menunjukkan bahwa hasil persentase dari pertemuan pertama sampai keenam yang meningkat dan memiliki rata-rata $83 \%$ dapat berjalan dengan baik. Pelaksanaan pembelajaran menggunakan Problem Based Learning dapat berpengaruh terhadap Higher Order Thinking Skills siswa. Jadi, dapat disimpulkan bahwa siswa yang menggunakan model Problem Based Learning memiliki Higher Order Thinking Skills lebih tinggi dibandingkan dengan siswa yang belajar menggunakan model konvensional. Hasil analisa data statistik pada Higher Order Thinking Skills siswa didapatkan nilai signifikansi dan rata-rata sebesar $(\bar{x}=80,12)$ pada kelas eksperimen dan $(\bar{x}=$ 60,63 ) pada kelas kontrol. 
Berdasarkan masalah, hipotesis, hasil, dan pembahasan penelitian maka saran yang dapat dikemukakan oleh peneliti kepada semua pihak. Pertama, Kepala Dinas Pendidikan Kota Malang agar mengadakan workshop tentang model Problem Based Learning dan HOTS. Kedua, Kepala Sekolah agar melakukan kegiatan sharing dan evaluasi terhadap kegiatan pembelajaran dan evaluasi tentang perkembangan proses berpikir siswa terutama keterampilan HOTS. Ketiga, guru menggunakan model pembelajaran Problem Based Learning untuk meningkatakan Higher Order Thinking Skills siswa secara terus menerus agar dapat melatih HOTS siswa serta dapat mnggabungkan model Problem Based Learning dengan model pembelajaran lain. Keempat, kepada peneliti selanjutnya untuk mengembangkan penelitian eksperimen menggunakan model PBL pada Higher Order Thinking Skills dengan memperhatikan banyaknya sampel pada tiap kelas guna kelancaran dan menggunakan media pembelajaran konkret lainnya.

\section{DAFTAR RUJUKAN}

Abosalem, Y. (2016). Assessment Techniques and Students' Higher-Order Thinking Skills. International Journal of Secondary Education, 4(1), 1. https://doi.org/10.11648/j.ijsedu.20160401.11

Assaraf, O. B. Z., \& Orion, N. (2010). System Thinking Skills at the Elementary School Level. Journal of Research in Science Teaching, 47(5), 540-563. https://doi.org/10.1002/tea.20351

Ball, A. L., \& Garton, B. L. (2010). Modeling Higher Order Thinking: The Alignment Between Objectives, Classroom Discourse, and Assessments. Journal of Agricultural Education, 46(2), 58-69. https://doi.org/10.5032/jae.2005.02058

Brookhart, S. M. (2010). How to Assess Higher-Order Thinking Skills in Your Classroom. (ASCD, ed.). Alexandria, VA.

Effendi, R. (2017). Konsep Revisi Taksonomi Bloom dan Implementasinya pada Pelajaran Matematika SMP. Jurnal Ilmiah Pendidikan Matematika, 2(1), 72-78. https://doi.org/10.26877/jipmat.v2i1.1483

Fatchiyah, F. (2016). Pengaruh PBL terhadap Kemampuan Berpikir Tingkat Tinggi Siswa Kelas V SD se-Gugus 01 Kretek. Basic Education, 5(18), 1-746.

Limbach, B., \& Waugh, W. (2010). Developing Higher Level Thinking. Journal of Instructional Pedagogies, 9.

Mairas Abd Rahman. (2016). The Impacts of 'Problem-Based Learning' Approach in Enhancing Critical Thinking Skills to Teaching Literature. International Journal of Applied Linguistics and English Literature, 5(6). https://doi.org/10.7575/aiac.ijalel.v.5n.6p.249

Noma, L. D., Prayitno, B. A., \& Suwarno. (2016). PBL untuk Meningkatkan Kemampuan Berpikir Tingkat Tinggi Siswa Kelas X SMA. Bioedukasi, 9(2), 62-66. https://doi.org/10.1364/OL.36.003374

Ramawati, I., Maryani, E., \& Mulyana, A. (2016). Pemanfaatan Lingkungan Sekitar sebagai Sumber Kemampuan Berpikir Kritis. GEA: Jurnal Pendidikan Geografi, 14(2),44-77.

Royantoro, F., Yusuf, I., \& Widyaningsih, S. W. (2018). Pengaruh Model Problem Based Learning terhadap Higher Order Thinking Skills Peserta Didik. Berkala Ilmiah Pendidikan Fisika, 6(3), 371-382. https://doi.org/10.20527/bipf.v6i3.5436

Sumantri, M. S. (2015). Strategi Pembelajaran: Teori dan Praktik di Tingkat Pendidikan Dasar. Jakarta: PT Raja Grafindo Persada.

Sumarmi. (2012). Model-Model Pembelajaran Geografi. Malang: Aditya Media.

Suprihatiningrum, J. (2017). Strategi Pembelajaran: Teori \& Aplikasi. Yogyakarta: Ar-Ruzz Media.

Tanujaya, B., Mumu, J., \& Margono, G. (2017). The Relationship between Higher Order Thinking Skills and Academic Performance of Student in Mathematics Instruction. International Education Studies, 10(11), 78. https://doi.org/10.5539/ies.v10n11p78

Trianto. (2010). Model Pembelajaran Terpadu Konsep, Strategi, dan Implementasinya dalam Kirikulum Tingkat Satuan Pendidikan (KTSP). Jakarta: Bumi Aksara.

Ulger, K. (2018). The Effect of Problem-Based Learning on the Creative Thinking and Critical Thinking Disposition of Students in Visual Arts Education. Interdisciplinary Journal of Problem-Based Learning, 12(1), 3-6. https://doi.org/10.7771/1541-5015.1649 